\title{
INCREASING SOCIAL SKILLS COMPETENCIES TO PREPARE FOR CAREERS OF CHILDREN WITH SPECIAL NEEDS
}

\author{
${ }^{1}$ Gangsar Ali Daroni, ${ }^{2}$ Gunarhadi, ${ }^{3}$ Edy Legowo \\ ${ }^{1,2,3}$ Magister Pendidikan luar Biasa, Pascasarjana Universitas Sebelas Maret
}

\begin{abstract}
This study aims to determine the efforts of extraordinary schools in improving social skills competence as an effort to prepare for careers of children with special needs. This study uses descriptive qualitative research methods. This research was conducted at SLB N Sukoharjo, SLB N Surakarta and SLB N Colomadu. Subjects in this study were six teachers and three principals in the Special School which were used as research sites. Research data were collected through interviews, observation, and documentation. The analysis technique in this study uses descriptive analysis. The results showed that efforts to improve social skills competencies to prepare for careers of children with special needs in extraordinary schools were carried out through the learning of social science. The social skill material taught is adapted to the child's ability. Barriers that occur in efforts to improve social skills are lack of parental support and a less inclusive social environment. The solution, schools can socialize with parents to teach social skills at home and socialization to the community environment to become an inclusive society.
\end{abstract}

Keywords: social skills, career, children with special needs

\section{Pendahuluan}

Karir merupakan bagian yang paling penting dalam kehidupan manusia. Karir yang baik akan mempengaruhi kualitas kehidupan seseorang (Hanani, 2016).. Setiap orang berharap perjalanan karir mereka berjalan lancar dan sukses. Sukses dalam karir erat kaitannya dengan pekerjaan yang mapan, kecukupan ekonomi dan status sosial yang baik. Berbagai upaya dilakukan untuk mempersiapkan karir yang baik dimasa depan (Atmaja, 2014). Salah satu upaya untuk mempersiapkan karir adalah melalui pendidikan.

Pendidikan merupakan salah satu upaya yang digunakan untuk memberikan bekal ilmu pengetahuan dan pengalaman yang dapat digunakan manusia untuk menjalani kehidupan sehari-hari (Noordyana, 2016). Melalui pendidikan, seseorang akan membuka jendela wawasan dan peluang dari berbagai sumber untuk mempersiapkan diri dalam menempuh

\footnotetext{
* Corresponding author: Gangsar Ali Daroni gangsaralidaroni@gmail.com

Published online at http://IJDS.ub.ac.id/

Copyright $\odot 2018$ PSLD UB Publishing. All Rights Reserved
}

jenjang karir. Selain itu, pendidikan juga dapat meningkatkan kualitas sumber daya manusia agar dapat bersaing didunia kerja (Mailani, 2018).

Sumber daya manusia yang berkualitas menurut UU No. 20 Tahun 2003 adalah manusia yang beriman, bertaqwa kepada Tuhan Yang Maha Esa, berakhlak mulia, sehat, berilmu, cakap, kreatif, mandiri dan menjadi warga Negara yang demokratis serta bertanggung jawab. Pemerintah Indonesia terus berupaya untuk memperbaiki pendidikan di Indonesia untuk dapat mencetak sumber daya manusia yang berkualitas agar dapat menempuh jenjang karir yang baik.

Upaya tersebut ditujukan bagi seluruh masyarakat di Indonesia tak terkecuali bagi anak berkebutuhan khusus. Anak berkebutuhan khusus adalah anak-anak yang menyandang kecacatan tertentu (disable children) baik secara fisik, mental dan emosional maupun yang mempunyai kebutuhan khusus dalam pendidikannya (children with special educational needs) (Suparno, 2007). Anak berkebutuhan khusus dibagi menjadi berbagai 
jenis antara lain tunanetra, tunarungu, tunagrahita, tunadaksa, tunalaras, dan autis.

Anak berkebutuhan khusus memiliki kelainan yang terjadi pada dirinya yang membuat mereka berbeda (Andesta, 2017). Oleh karena itu, bekal persiapan karir untuk dapat bersaing di dunia kerja sangat diperlukan bagi anak berkebutuhan khusus. Mereka memerlukan pendidikan yang dapat memberikan kompetensi untuk menggapai karir yang mereka inginkan sesuai dengan kemampuan yang mereka miliki (Khairun, Sulastri, \& hafina, 2015).

Sekolah luar biasa merupakan salah satu lembaga pendidikan formal yang menyediakan layanan pendidikan bagi anak berkebutuhan khusus. (Latifah, 2015: 11). Melalui sekolah luar biasa, anak berkebutuhan khusus dapat menempuh jenjang pendidikan dari TK, SD, SMP hingga SMA. Sekolah luar biasa berperan memberikan bekal kompetensi kepada anak berkebutuhan khusus untuk menggapai karir mereka setelah lulus dari sekolah luar biasa. Salah satu kompetensi yang penting untuk diberikan kepada anak berkebutuhan khusus dalam mempersiapkan karir adalah keterampilan sosial (Siska, 2011).

Keterampilan sosial adalah kemampuan untuk menciptakan hubungan sosial yang serasi dan memuaskan, penyesuaian terhadap lingkungan sosial dan memecahkan masalah sosial yang dihadapi serta mampu mengembangkan aspirasi dan menampilkan diri, dengan ciri saling menghargai, mandiri, mengetahui tujuan hidup, disiplin dan mampu membuat keputusan (Sepriyan dalam Maryani \& Syamsudin, 2009). Kompetensi keterampilan sosial sangat diperlukan oleh anak berkebutuhan khusus agar mereka dapat percaya diri dan dapat melakukan hubungan sosial yang baik ketika menempuh karir setelah lulus dari sekolah. Ketrampilan social yang baik dapat membuat anak berkebutuhan khusus dapat diterima baik di masyarakat dan dunia karir selanjutnya.

Penelitian ini bertujuan untuk mengetahui upaya sekolah luar biasa dalam meningkatkan kompetensi keterampilan sosial sebagai salah satu upaya mempersiapkan karir anak berkebutuhan khusus.

\section{Metode Penelitian}

Penelitian ini menggunakan metode penelitian kualitatif deskriptif. Penelitian ini dilakukan di SLB N Sukoharjo, SLB N Surakarta dan SLB N Colomadu. Subjek dalam penelitian ini adalah enam guru dan tiga kepala sekolah di Sekolah Luar Biasa yang digunakan sebagai tempat penelitian.

Data penelitian dikumpulkan melalui wawancara, observasi dan dokumentasi. Wawancara dilakukan kepada guru untuk mengetahui cara meningkatkan keterampilan sosial anak berkebutuhan khusus. Observasi dilakukan peneliti untuk mengetahui secara langsung pelaksanaan upaya peningkatan keterampilan sosial anak berkebutuhan khusus di sekolah luar biasa untuk mempersiapkan karir mereka.

Teknik analisis dalam penelitian ini menggunakan analisis deskriptif. Analisis deskriptif adalah cara menganalisis data penelitian dengan cara mendeskripsikan secara detail data yang diperoleh dari suatu penelitian.

\section{Hasil dan Pembahasan}

\section{A. Upaya Sekolah Luar Biasa dalam Meningkatkan Kompetensi Keterampilan Sosial Anak Berkebutuhan Khusus}

Berdasarkan hasil wawancara dan observasi yang dilakukan oleh peneliti di tigas sekolah luar biasa yang digunakan sebagai subjek penelitian, berikut ini upaya peningkatan kompetensi keterampilan sosial untuk mempersiapkan karir anak berkebutuhan khusus di sekolah luar biasa:

Peningkatan keterampilan sosial anak berkebutuhan khsusus di sekolah luar biasa dilakukan secara terintegrasi pada mata pelajaran ilmu pengetahuan sosial. Mata pelajaran ilmu pengetahuan sosial merupakan mata pelajaran yang berisi teori-teori yang mana nantinya diterapkan dalam kehidupan sehari-hari. Hampir dari seluruh proses kegiatan manusia menerapkan apa yang ada dalam pelajaran ilmu pengetahuan sosial, sehingga pelajaran ilmu pengetahuan sosial penting untuk diajarkan kepada peserta didik. Pelajaran ilmu pengetahuan sosial menjadi suatu mata pelajaran yang dapat mengantarkan peserta didik untuk dapat menjawab masalah- 
masalah mendasar tentang individu, masyarakat, pranata sosial, problem sosial, perubahan sosial, dan kehidupan masyarakat berbangsa dari waktu ke waktu.

Didalam menyampaikan pembelajaran ilmu pengetahuan sosial untuk meningkatkan keterampilan sosial anak berkebutuhan khusus, ada berbagai cara yang berbeda disesuaikan dengan kemampuan anak. Sekolah luar biasa yang digunakan sebagai subjek adalah sekolah luar biasa negeri, sehingga segala ketunaan diterima di sekolah luar biasa ini. Oleh karena itu, pembelajaran kepada siswa juga berbeda.

Siswa yang memiliki kemampuan intelektual dibawah rata-rata, sulit memahami materi yang diberikan oleh guru. Mereka membutuhkan waktu yang lebih lama untuk memahami suatu materi yang diberikan guru. Materi keterampilan sosial yang diberikan kepada anak dengan intelektual juga lebih sederhana dan yang mudah dipahami anak. Keterampilan-keterampilan sosial sederhana seperti menyapa, sopan santun, dan kepercayaan diri ketika berbaur dengan lingkungan sosial. Hal tersebut dapat dilakukan dengan melakukan permainan-permainan kelompok seperti gobak sodor, ulat memanjang dan lain-lain.

Kegiatan mengajak siswa ke lingkungan masyarakat secara langsung untuk mempraktekkan materi keterampilan sosial dapat dilakukan dengan cara mengajak ke pasar melakukan kegiatan berbelanja, mengajak ke stasiun untuk berbaur dengan masyarakat di lingkungan transportasi umum, mengajak siswa beribadah di tempat beribadah umum seperti masjid secara berjamaah, dan kegiatan lain yang dapat memberikan pengalaman langsung kepada siswa. Kegiatan tersebut dapat dilakukan secara berulang-ulang hingga anak dapat melakukan kegiatan-kegiatan sosial secara mandiri dan percaya diri.

Untuk siswa yang tidak memiliki hambatan dalam intelektual juga diajarkan sama dengan kegiatan diatas, namun perlu diberikan ketrampilan tambahan yang dapat membekali mereka ke jenjang karir berikutnya. Ketrampilan yang dapat diajarkan kepada siswa dapat berupa bagaimana bergaul dengan teman sejawat, orang yang lebih tua, bagaimana menjaga bahasa tubuh yang baik dan bagaimana berperan baik dalam masyarakat.

Upaya tersebut dapat dilakukan dengan mengajak siswa untuk mengikuti organisasi- organisasi untuk meningkatkan keterampilan sosial mereka. Anak tunarungu dapat mengikuti komunitas anak tuli di Surakarta, anak tunanetra dapat mengikuti pertuni yaitu komunitas bagi anak tunanetra. Hal tersebut dapat menambah kompetensi ketrampilan sosial anak berkebutuhan khusus.

Selain itu, program magang kerja di tempat kerja sesungguhnya disediakan di sekolah luar biasa untuk memberikan pengalaman kerja secara langsung kepada siswa. Melalui magang tersebut, guru memberikan arahan untuk dapat belajar bersosialisasi dengan masyarakat atau lingkungan sosial di dalam dunia kerja. Semua itu merupakan upaya sekolah luar biasa dalam meningkatkan keterampilan sosial untuk mempersiapkan karir anak berkebutuhan khusus.

\section{B. Hambatan dalam Peningkatan Keterampilan Sosial Anak Berkebutuhan Khusus}

Dalam pelaksanaan upaya peningkatan keterampilan sosial untuk mempersiapkan karir anak berkebutuhan khusus, ada beberapa hal yamg peneliti temukan ketika melakukan pengumpulan data di tiga sekolah luar biasa yang dijadikan subjek penelitian. Hambatan tersebut antara lain:

1) Dukungan Orang Tua yang Kurang

Beberapa orang tua anak berkebutuhan khusus kurang mendukunga program peningkatan keterampilan sosial anak berkebutuhan khusus. Mereka masih malu untuk mengajak anaknya dalam berinteraksi sosial dengan masyarakat. Padahal pembelajaran yang dilaksanakan di sekolah, apabila dapat setiap hari dipraktekkan orang tua dirumah tentu hasilnya akan lebih optimal. Namun sebaliknya, orang tua kurang dapat mengajak anaknya berinteraksi sosial dimasyarakat dan tidak membekali mereka keterampilan sosial dirumah dan lingkungan sekitar rumah.

2) Lingkungan Sosial Yang Kurang Inklusif

Dalam melaksanakan kegiatan pembelajaran berineraksi sosial langsung dengan masyarakat, masih ada masyarakat yang menganggap rendah anak berkebutuhan khusus. Mereka masih ada yang mengejek dan menjauhi mereka karena kelainan yang mereka miliki. Hal tersebut menjadi salah satu 
penghambat karena dapat membuat siswa menjadi kurang percaya diri saat melakukan interaksi dengan masyarakat karena takut di ejek atau direndahkan.

\section{Solusi Untuk Mengatasi Hambatan}

Upaya yang dilakukan oleh sekolah untuk mengatasi hambatan yang terjadi dalam upaya meningkatkan keterampilan sosial untuk mempersiapkan karir anak berkebutuhan khusus adalah dengan melakukan sosialisasi kepada orang tua agar dapat mengajarkan keterampilan sosial sederhana kepada anaknya, dan mengajak anak untuk dapat berbaur langsung dengan masyarakat. Dengan dukungan orang tua, maka anak akan memiliki keterampilan sosial yang baik di lingkungan masyarakat dan dapat hidup mandiri dikemudian hari.

Solusi bagi lingkungan yang kurang inklusif adalah memberikan sosialisasi kepada lingkungan masyarakat mengenai anak berkebutuhan khusus dan bagaiman bersikap kepada mereka. Memberikan pengetahuan bahwa mereka sama seperti kita yaitu manusia ciptaan Tuhan, hanya saja mereka memiliki kemampuan yang berbeda dengan manusia pada umumnya. Semua orang harus dapat menerimanya dengan baik agar mereka tidak merasa rendah diri ketika bergaul. Mengadakan pentas bakat anak berkebutuhan khusus juga menjadi salah satu upaya untuk memberitahukan kepada masyarakat bahwa mereka bisa berprestasi dan memiliki bakat yang luar biasa.

\section{KESIMPULAN}

Berdasarkan hasil penelitian diatas, dapat disimpulkan bahwa upaya peningkatan kompetensi keterampilan sosial untuk mempersiapkan karir anak berkebutuhan khusus di sekolah luar biasa dilakukan melalui pembelajaran ilmu pengetahuan sosial. Materi keterampilan sosial yang diajarkan, disesuaikan dengan kemampuan anak. Hambatan yang terjadi dalam upaya peningkatan keterampilan sosial adalah dukungan orang tua yang kurang dan lingkungan sosial yang kurang inklusif. Solusinya, sekolah dapat melakukan sosialisasi kepada orang tua untuk mengajarkan keterampilan sosial dirumah dan sosialisasi kepada lingkungan masyarakat agar menjadi masyarakat yang inklusif.

\section{DAFTAR PUSTAKA}

Andesta, N. (2017). Pengalaman Keagamaan Anak Berkebutuhan Khusus (Studi di SLB A Bina Insani Kelurahan Gedung Meneng Kecamatan Rajabasa Bandar Lampung) (Skripsi, Universitas Islam Negeri Raden Intan Lampung).

Atmaja, T.T. (2014). Upaya Meningkatkan Perencanaan karir Siswa Melalui Bimbingan Karir dengan Penggunaan Media Modul. PSIKOPEDAGOGIA. 3(2):58-68.

Hanani, Z. (2016). Pengembangan Kartu Karir Sebagai Media Dalam Bimbingan Karir Siswa $S D$ Negeri Samirono (Skripsi. Universitas Negeri Yogyakarta).

Khairun, D.Y., Sulastri, M.S., \& Hafina, A. (2015). Layanan Bimbingan Karir Dalam Peningkatan Kematangan Eksplorasi Karir Siswa. Universitas Pendidikan Bandung. Diperoleh dari http://file.upi.edu/.

Latifah, A. (2015). Analisis Tenaga Pendidik Di Sekolah Luar Biasa Negeri 1 Bantul (Skripsi. Universitas Negeri Yogyakarta).

Mailani, E. (2018). Upaya Meningkatkan Hasil Belajar Matematika Pada Materi Pecahan Melalui Permainan Monopoli Pecahan. Jurnal Handayani PGSD FIP UNIMED, 4(1), 1-14.

Maryani, E, \& Syamsudin, H. (2009). Pengembangan Program Pembelajaran IPS Untuk Meningkatkan Kompetensi Keterampilan Sosial. Jurnal Penelitian, 9(1), 115.

Noordyana, M. A. (2016). Meningkatkan Kemampuan Berpikir Kritis Matematis Siswa melalui Pendekatan Metacognitive Instruction. Jurnal Pendidikan Matematika STKIP Garut, 5(2), 120-127.

Siska, Y. (2011). Penerapan Metode Bermain Peran (Role Playing) Dalam Meningkatkan Keterampilan Sosial Dan Keterampilan Berbicara Anak Usia Dini (Penelitian Tindakan Kelas di Kelas B Taman kanak-kanak Al Kautsar Bandar Lampung Tahun Ajaran 20102011). Jurnal Universitas Pendidikan Indonesia, edisi khusus. (2), 31-37.

Suparno. (2007). Pendidikan Anak Berkebutuhan Khusus. Konsorsium Program S1 PGSD: Direktorat Jendral Pendidikan Tinggi. 